\title{
Does the COVID-19 Outbreak Constitute a Force Majeure Event? A Pandemic Impact on Construction Contracts
}

\author{
Seng Hansen ${ }^{1,2, *}$ \\ ${ }^{1}$ Universitas Agung Podomoro, INDONESIA \\ ${ }^{1}$ Central Park Mall $3^{\text {rd }}$ Floor-Unit 112, Jalan Let. Jend. S. Parman Kav.28, West Jakarta, 11470 \\ ${ }^{2}$ Royal Melbourne Institute of Technology, AUSTRALIA \\ 124 La Trobe Street, Melbourne VIC 3000 \\ *Corresponding authors: seng.hansen@gmail.com
}

SUBMITTED 23 March 2020 REVISED 8 April 2020 ACCEPTED 15 April 2020

\begin{abstract}
The emergence of novel coronavirus disease 2019 (COVID-19) at the end of 2019 has transformed from an epidemic to a pandemic disaster. As of 12 April 2020, this outbreak has spread to more than 210 countries and territories and caused 108,837 deaths. The development of this outbreak has resulted in the closure of several major cities in the world (such as Wuhan, Daegu, and Manila) to country-wide lockdowns as observed in Italy and Malaysia. This also affects the construction sector as a labor-intensive industry. Force majeure has become one of the critical points of discussion, considering that this provision allows a contract party to hinder from fulfilling its obligations on the grounds that events are beyond a party's control. Nevertheless, the application of this provision often faces challenges considering that in prior legal cases, the Courts tend to interpret this clause narrowly. Thus, it would be problematic when the force majeure clause does not include an epidemic outbreak as a force majeure event in the contract. This paper aims to explore the potential of the COVID-19 outbreak as a force majeure event in construction contracts. A qualitative approach consisting of two-step interdependent methods was done to highlight the fundamental elements of force majeure and to analyze whether the COVID-19 outbreak constitutes a force majeure event or not. Finally, a decision model was developed to assist the contracting parties in determining the COVID-19 outbreak potential as a force majeure event. This paper contributes since research related to the impacts of epidemic or pandemic outbreaks on the construction industry has not been intensified.
\end{abstract}

KEYWORDS Construction Industry; Coronavirus; COVID-19 Outbreak; Epidemic/Pandemic; Force Majeure.

(c) The Author(s) 2020. This article is distributed under a Creative Commons Attribution-ShareAlike 4.0 International license.

\section{INTRODUCTION}

Since the outbreak of the novel coronavirus infection, later named as the coronavirus disease 2019 (COVID-19) in Wuhan, China at the end of 2019 , this epidemic has quickly spread to various countries in the world and posed a global health threat. As of 12 April 2020, data have shown that more than 1,780,714 confirmed cases were identified in 210+ countries (Worldometer, 2020). This ongoing development has caused the World Health Organization (WHO) announced this outbreak as a pandemic on 11 March 2020.

This outbreak has affected many people and industries. Recent development shows the impact of this outbreak on the global economy. Several major cities and countries in the world have taken decisive actions to prevent and mitigate the spread of this outbreak. China became the first country to implement the lockdown policy in several cities. This step was followed by other infected countries such as South Korea, Japan, Italy and Malaysia. This certainly has an impact on various industrial sectors such as health, tourism, real estate, and construction.

While the future is uncertain, it is not uncommon for the construction industry to anticipate this. In fact, this industry has long been regarded as an industry full of risks and uncertainties. Hence, a force majeure term has been widely used in construction contracts that govern the events, consequences, and relationships of the parties when a force majeure event occurs. As a contract provision, it serves as a risk distribution between 
parties when the event occurs. Although important, in many cases force majeure clauses are not well-drafted resulting in conflicts and disputes between parties. Furthermore, not all force majeure clauses include an epidemic outbreak as a force majeure event.

This study found limited academic research that focused on discussing the epidemic outbreak as a force majeure event in construction industry. Thus, it aims to explore the possibility of the COVID-19 outbreak being considered a force majeure event. It raises two main questions: (1) what constitute a force majeure event? and (2) can the COVID-19 outbreak be considered as a force majeure event?

To achieve that aim, this paper used an integrated literature review to investigate various definitions, scopes, and issues concerning force majeure provisions in construction contracts. This step is carried out to identify the fundamental aspects that constitute a force majeure event. Next, the case study of COVID-19 outbreak is analyzed based on these aspects to determine whether this outbreak can be considered as a force majeure event. Finally, the author develops a decision model to assist parties in identifying a potential event as a force majeure event in their construction contracts.

\section{LITERATURE REVIEW}

\subsection{The COVID-19 Outbreak}

Coronavirus is one of the main pathogens that attack the human respiratory system. It represents a continuous pandemic threat that humans have experienced (El Zowalaty \& Järhult, 2020) with the emergence of previous outbreaks of coronaviruses namely the severe acute respiratory syndrome (SARS-CoV) in 2002 and Middle East Respiratory Syndrome (MERS-CoV) in 2012 (Chang, Yan \& Wang, 2020; Rothan \& Byvydy, 2020). Almost the same as both, the COVID-19 cases ranged from diagnosed with respiratory infection to multi-organ failure with the risk of death.

It was first identified in December 2019 and as of 12 April 2020, it has caused 108,837 deaths out of
1,780,714 COVID-19 cases (Worldometer, 2020). China is considered as the source of the spread of the virus and has one of the most cases with numbers up to 82,052 cases. Although its surrounding countries currently have an increase in cases, USA becomes the most infected country with 533,088 cases, followed by Spain with 163,027 cases, Italy with 152,271 cases, and France with 129,654 cases.

The infection is spread by human-to-human transmission via droplets or direct contact with a mean incubation period of 6.4 days and a basic reproduction number of 2.24 - 3.58 (Lai et al., 2020). Another study mentions that the COVID19 infection symptoms appear after a mean incubation of 5.2 days. It was found that this period is dependent on the age and immune system of the patients (Rothan \& Byvydy, 2020).

Many countries have reacted to prevent the spread of this outbreak with robust mitigation measures such as cities or country-wide lockdowns, border closures, application of travel bans from infected countries, and other domestic health procedures. This certainly has an impact not only to socio-economic aspects, but also cultural and attitudes such as physical distancing recommendation. Despite all the efforts and research that has been done, there is still no vaccine against coronaviruses which makes it a serious global threat (El Zowalaty \& Järhult, 2020).

\subsection{Force Majeure Clause}

Force majeure is a civil law concept (Ezeldin \& Helw, 2018) since it was originated from the French Law known as Code Civil. It is a legal concept that exists in many civil law jurisdictions all over the world (Akbiyikli, Dikmen \& Eaton, 2011). A force majeure clause is a contract provision that entitles a party to stop performing its contractual obligations if certain circumstances occur beyond its control so that performance becomes impossible, inadvisable, illegal, or impractical (Corrada, 2007). It is related to physical property loss or personal damage (Fawzy \& El-Adaway, 2012). As a risk, Li \& Zou (2012) considered two types of force majeure 
events, i.e. construction and political force majeure events.

An event is considered as a force majeure event if it is external, unexpected, and unavoidable (Azfar, 2012; Ezeldin \& Helw, 2018). There are two common consequences of force majeure events, i.e. termination and suspension of the project (Hagedoorn \& Hesen, 2007; Ezeldin \& Helw, 2018). If a force majeure event leads to project termination, each party bears his own risk and consequences. In some cases, the contractor might be compensated for the part of work already performed prior to the force majeure event (Hagedoorn \& Hesen, 2007). Whereas if a suspension occurs due to a force majeure event, then the contractor is usually entitled to an extension of time.

Although it is one of the important provisions in construction contracts, the definition and scope of force majeure concept varies worldwide. Augenblick and Rousseau (2012) concluded that different laws and jurisdictions apply different approaches to determine force majeure events. This difference can also be found in various standard forms of construction contracts, especially related to the scope of the force majeure event. Therefore, this paper discusses the different concepts of force majeure and its events in light of different jurisdictions and standard forms of construction contracts.

\section{METHODS}

This study uses a two-step interdependent methodology in which the author (1) highlight the fundamental elements that constitute a force majeure by investigating the various definitions, scopes, and issues concerning force majeure provision in construction contracts governed either by civil law or common law jurisdiction; and (2) provide a comparative analysis with a case study of COVID-19 outbreak with the aim to identify whether COVID-19 outbreak can be considered as a force majeure event. Table 1 below presents the case study summary. The first step involves an integrative literature review which reviews, critique, and synthesizes relevant literature so that new insights appear (Torraco, 2005; Hansen, Too \& Le, 2018). The relevant literature comes from various laws, regulations, law cases, and academic journals related to force majeure both from the perspective of civil law and common law jurisdictions. This is followed by collecting data on the latest development of the COVID-19 outbreak both nationally (in Indonesian context) and internationally. These data include media reports, legal notes and opinions, company publications, and government reports relevant to the COVID-19 outbreak. A comparative analysis is carried out to assess whether the case study constitutes a force majeure event.

\section{RESULTS}

\subsection{Finding 1: what constitute a force majeure?}

Force majeure is one of the most critical risks in the construction activities. Although the term 'force majeure' is often found in construction contracts, the requirements to apply its principle vary worldwide (Ezeldin \& Helw, 2018). Therefore, this section discusses the definitions and requirements of force majeure in different jurisdictions and standard forms.

\subsubsection{Force majeure in civil law jurisdictions}

Construction contracts made within the civil law jurisdiction automatically recognize force majeure whether or not it is written into the contracts. In this section, force majeure principles from three civil law jurisdictions, i.e. French, China (PRC), and Indonesia, were compared.

Table 1. Summary of case study

\begin{tabular}{lllll}
\hline Case & Type & \multirow{2}{*}{ First identified case } & Virus strain/causes & Statistics (as of 12 April \\
& & & & $2020)$ \\
\hline $\begin{array}{l}\text { Coronavirus } \\
\text { disease 2019 }\end{array}$ & $\begin{array}{l}\text { Epidemic (since Dec } \\
\text { 2019), later become }\end{array}$ & Wuhan, Hubei & Severe acute respiratory & $1,780,714$ cases \\
(COVID-19) & pandemic (March & province, China & syndrome coronavirus 2 & 108, deaths \\
& 2020) & & (SARS-CoV-2) & $210+$ territories \\
\hline
\end{tabular}


The force majeure term was first introduced in the French Civil Code, also known as the Napoleonic Civil Code. Due to significant changes over two hundred years, amendment has been made to this Civil Code which now known as the 2016 Ordinance. In this new French Civil Code, force majeure is mentioned in eight articles with two most important articles are Articles 1218 and 1351. The first article reads "In contractual matters, there is a force majeure where an event beyond the control of the debtor, which could not reasonably have been foreseen at the time of the conclusion of the contract and whose effects could not be avoided by appropriate measures, prevents performance of his obligation by the debtor. If the prevention is temporary, performance of the obligation is suspended unless the delay which results justifies termination of the contract. If the prevention is permanent, the contract is terminated by operation of law and the parties are discharged from their obligations under the conditions provided by articles 1351 and 1351-1." Meanwhile, Article 1351 reads "Impossibility of performing the act of performance discharges the debtor to the extent of that impossibility where it results from an event of force majeure and is definitive unless he had agreed to bear the risk of the event or had previously been given notice to perform."

The concept of force majeure is also applicable in the General Rules of the Civil Law of the PRC 2017 and indicated in the Chapter VIII concerning Civil Liability, Article 180: "No civil liability is borne in case of failure to perform civil duties due to force majeure, unless otherwise provided by law. Force majeure means unforeseeable, unavoidable and unconquerable objective situation." Similarly, the Contract Law of the PRC 1999, Article 117 defines force majeure as "any objective circumstance which is unforeseeable, unavoidable and insurmountable." Article 118 of the Contract Law further explains the duty of a party who is unable to perform a contract performance due to force majeure to notify the other party promptly to mitigate the loss, and shall provide proof of force majeure within a reasonable time.
Meanwhile, the Indonesian Civil Code contains force majeure can be found mainly in Articles 1244 and 1245 . The formula of force majeure in the Indonesian Civil Code can be detailed as follows. First, the event that caused the force majeure must be "unexpected" by the parties, or not included in the basic assumption at the time the parties make the contract (Article 1244). Second, the event cannot be held responsible to the party that has to carry out the work (the debtor) (Article 1244). Third, the event that caused the force majeure was beyond the debtor's fault (Article 1244). Fourth, the event that caused the force majeure was "beyond the mistakes of the parties" (Article 1545). Fifth, the parties are not in a state of bad faith (Article 1244). Sixth, if a force majeure occurs, then the contract will be null and void, and as far as possible the parties are returned as if the agreement was never conducted (Article 1545). Seventh, if a force majeure occurs, then the parties may not claim compensation (1245 and 1553). However, because the contract concerned was terminated due to force majeure, the party who had performed his obligation may claim for the object he had delivered in the exchange (Article 1545).

\subsubsection{Force majeure in common law jurisdictions}

The concept of force majeure which applies in civil law countries is relatively unknown in common law countries (Amkhan, 1991). However, the use of this term is sometimes recognized and applied in contracts governed by common law, which have been approved in advance by contracting parties. In other words, while a force majeure provision is never implied under common law, it can be raised in the contract when the parties have agreed to it.

On the other hand, although the force majeure concept is unknown in the common law countries, the doctrine of the impossibility of performance and frustration in the UK and commercial impracticability in the US may apply, which is somewhat similar in certain aspects to the force majeure concept (Augenblick \& Rousseau, 2012). Hence, Ezeldin and Helw (2018) concluded that the general idea of force majeure 
principle has been applied in one form or another by most legal systems worldwide.

Since there is no concept of force majeure in common law legal system, case law or precedent established from previous legal cases related to force majeure can be used. For example, a case law from Singapore concerning the effect of the Indonesian sand ban on construction contract has been observed where the Court considers that a force majeure event must be beyond the control of the parties and reasonable steps must be taken to avoid its effects (Holcim Singapore Pte. Ltd v Precise Development Pte Ltd [2011] SGCA 1). Similar principles have been observed as well in the case of Seadrill Ghana Operations Ltd v Tullow Ghana Ltd [2018] EWHC 1640. In this case, the Court highlighted that the force majeure event must be causative to the contractual breach and that reasonable steps to avoid the effects of force majeure event must be taken.

Another example of an event not being causative to the contractual breach is observed in the Thames Valley Power Ltd v Total Gas \& Power Ltd [2006] 1 Lloyd's Rep. 441. The Court provides principles for a party to be released from its obligations on the grounds of force majeure: (i) the existence of force majeure (an event beyond its control), (ii) the event has resulted in a failure of a party to fulfill one or more of its obligations or has caused a party to be unable wholly or partly to carry out such obligations, (iii) that notwithstanding the exercise of reasonable diligence and foresight, it was or would have been unable to prevent or overcome, (iv) the affected party gave notice in writing of such force majeure as soon as possible after the occurrence of the cause relied on.

One case arising from the 2003 SARS epidemic in Hong Kong ruled that the force majeure event must adversely affect the fulfillment of contractual obligations of the parties (Li Ching Wing v Xuan Yu Xiong [2004] 1 HKLRD 754). In this case, the tenant applicant argued that due to an isolation order for 10 days, the tenancy agreement was frustrated. However, the Court held that even though the SARS outbreak could be considered as an unforeseeable event, the impact did not radically alter the fundamental rights and obligations arising from the tenancy agreement.

\subsubsection{Force majeure in standard forms of construction contract}

The term force majeure is often found in standard forms of construction contracts, such as the FIDIC (Fédération Internationale des IngénieursConseils) Red Book, JCT (Joint Contracts Tribunal) Standard Building Contracts, and New Engineering Contract (NEC). The term force majeure in FIDIC Red Book 1999 is found at Clause 19 which now has been updated with the term 'exceptional event' in the 2017 Red Book. In this second edition, this term is dealt with in Clause 18 which defined it as an event or circumstance which fulfills four conditions: (i) is beyond a party's control; (ii) the party could not reasonably have provided against before entering into the contract; (iii) having arisen, such party could not reasonably have avoided or overcome; and (iv) is not substantially attributable to the other party.

Subclause 18.1 of the 2017 FIDIC Red Book includes a wide list of exceptional events which includes but not limited to: natural catastrophes, war, terrorism, revolution, and riot. This continues with Subclause 18.2 which states the obligations of the affected party to give a Notice to the other party within 14 days after the affected party became aware, or should have become aware, of the exceptional event. Under Subclause 18.3, the duty to minimize any delay in the performance of the contract as a result of an exceptional event is explained. The consequences of an exceptional event are presented in Subclause 18.4. According to Subclause 18.5, if the work progress is prevented for a continuous period of 84 days, then either party may provide a notice of termination. This subclause further provides the basis of payable amount upon optional termination. Subclause 18.6 describes the conditions of release from performance under the law.

The 2017 Red Book does not clearly list epidemics or global diseases as an event in the force majeure 
provision. However, it is explained that the list is not limited to the stated events provided that the conditions that constitute an exceptional event are satisfied. According to the Insight report by Fenwick Elliot (2014), epidemic outbreaks (in this case Ebola pandemics) are considered most likely to fall into the natural catastrophe category. The term 'epidemic' is actually found in Clause 8.5 which explains that the contractor shall be entitled to extension of time if unforeseeable shortages in the availability of personnel or goods caused by epidemics or governmental actions occur.

The force majeure provision under NEC4 is found at Clause 19 which deals with 'prevention' arising from an event which (i) stops the contractor completing the work at all, or by the date shown on the accepted program, (ii) neither party could prevent, and (iii) have such a small chance of occurring that it would have been unreasonable to have allowed for it. Thus, there are three tests that can be used to justified whether an event fall within this clause, namely: (1) there must be no reasonable way of completing the works on time, (2) neither party could prevent with the use of reasonable measures, and (3) the event must be unreasonable (Fenwick Elliot, 2014). In NEC4, examples of force majeure events are found in the Subclause 80.1 which deals with client's liabilities. Here, it states that loss of or damage to the works, plant and materials due to force majeure events such as war, revolution, riots, and radioactive contamination are client's liabilities.

Clause 15 of NEC4 deals with early warning which provides notification procedure for any matter or event which could increase the total cost, delay completion, delay meeting a milestone, or impair the work performance. Under Subclause 60.1(19), force majeure events are compensation events which means that contractor can submit a claim to recover cost. For this, Subclause 62.1 explains that the project manager may instruct the contractor to submit alternative quotations for other methods of dealing with the compensation event which it considers practicable. The consequences of a compensation event such as changes of the contract price, completion date and milestone can be found in Subclause 66.2. According to Subclause 91.7, only the client who may terminate the contract if a force majeure event occurs. Meanwhile, Subclause 91.5 states that either party may terminate the contract if the parties have been released under the law from further performance.

The last standard forms of construction contract discussed is the JCT Standard Building Contract with Quantities (SBC/Q) 2016. The term force majeure is listed as one of the 'relevant events' under Subclause 2.29.15. However, no further explanation was found regarding force majeure definition and conditions. The scope of force majeure events can be found in the Subclause 2.29.11 to 2.29.13 which are listed as other relevant events. These include civil commotion, threat of terrorism, strike, lock-out, and the government intervention. Clause 2.27 requires the contractor to provide notice when a relevant event occurs. The consequences of a force majeure event are found in Subclause 2.28 regarding extension of time. Subclause 8.11 provides termination by either party due to force majeure in circumstances where the carrying out of the whole or substantially the whole of the uncompleted works is suspended for the relevant continuous period of the length stated in the contract particulars. According to Subclause 8.12.3, the only possibility that a contractor can recover costs depends on the employer's option.

Table 2 presents the summary of force majeure aspects from these three standard forms which consists of (1) the definition of force majeure, (2) the scope of force majeure events, (3) force majeure notification, (4) obligation to minimize, (5) possible consequences, (6) conditions to terminate, (7) conditions for possible payment, and (8) release of performance under the law.

\subsection{Finding 2: Indonesian Government Responses to the COVID-19 Outbreak}

As the largest nation in Southeast Asia, Indonesia has also been infected by the COVID-19 outbreak. The latest data shows that there are 3,842 confirmed cases in Indonesia with 327 deaths and 286 recovered cases. The outbreak has infected all 
34 provinces with Jakarta as the most infected province. To minimize the impacts of this outbreak, several protocols have been issued by the Indonesian government. One of them is related to construction sector.

In general, the Indonesian government recognizes the COVID-19 outbreak as a force majeure event which influences the continuity of the execution of construction contracts in Indonesia. The impacts may include disruptions to the supply of goods and/or materials to the construction site, quarantined project labor, and project suspension or termination (LKPP, 2020). In order to prevent the spread of COVID-19 outbreak in construction services, the government through the Ministry of Public Works and Housing has issued a Ministerial Instruction No. 02/IN/M/2020 on 27 March 2020. It provides a protocol for COVID-19 outbreak prevention in construction services sector as presented in Table 3.

Table 2. Summary of force majeure aspects in standard forms of construction contract

\begin{tabular}{|c|c|c|c|}
\hline Aspects & FIDIC & NEC & JCT \\
\hline Type \& year & Red Book (2017) & NEC4 (2017) & SBC/Q (2016) \\
\hline Term used & Exceptional events & $\begin{array}{l}\text { Part of compensation } \\
\text { events }\end{array}$ & $\begin{array}{l}\text { Force majeure (part of } \\
\text { relevant events) }\end{array}$ \\
\hline Definition & Subclause 18.1 & Clause 19.1 & Subclause 2.29 .15 \\
\hline Scope of events & Subclause 18.1 & Subclause 80.1 & Subclause $2.29 .11-2.29 .13$ \\
\hline Is 'epidemic' stated? & $\begin{array}{l}\text { Not as a force majeure } \\
\text { events listed in subclause } \\
18.1 \text {. } \\
\text { Yes (at subclause } 8.5(d) \text { ) }\end{array}$ & No & No \\
\hline Notice & Subclause 18.2 & Clause 15 & Subclause 2.27 \\
\hline $\begin{array}{l}\text { Obligation to } \\
\text { minimize impacts }\end{array}$ & Subclause 18.3 & Subclause 62.1 & - \\
\hline Consequences & Subclause 18.4 & Subclause 66.2 & Subclause 2.28 \\
\hline Termination & Subclause 18.5 & Subclause 91.7 & Subclause 8.11 \\
\hline $\begin{array}{l}\text { Payment for } \\
\text { completed work }\end{array}$ & Subclause 18.5 & Subclause 60.1(19) & Subclause 8.12 .3 \\
\hline $\begin{array}{l}\text { Release from } \\
\text { performance under } \\
\text { the law }\end{array}$ & Subclause 18.6 & Subclause 91.5 & - \\
\hline
\end{tabular}

Table 3. Mechanism of the COVID-19 outbreak prevention in construction services sector

\begin{tabular}{|c|c|c|c|}
\hline No & Stage & Responsibility & Key Points \\
\hline 1 & $\begin{array}{l}\text { Establish a COVID-19 } \\
\text { prevention task force }\end{array}$ & $\begin{array}{l}\text { Employer and } \\
\text { contractor }\end{array}$ & $\begin{array}{l}\text { At least five personnels } \\
\text { The tasks include socialization, education and promotion of } \\
\text { COVID-19 prevention on sites; coordination with the Ministry's } \\
\text { COVID-19 task force; monitoring workers' health conditions, } \\
\text { etc. }\end{array}$ \\
\hline 2 & $\begin{array}{l}\text { Identify the COVID-19 } \\
\text { outbreak potential on } \\
\text { sites }\end{array}$ & $\begin{array}{l}\text { Employer and } \\
\text { contractor }\end{array}$ & $\begin{array}{l}\text { The task force determines: } \\
\text { Identification of potential project location risks to the COVID- } \\
19 \text { infected areas } \\
\text { Compatibility of health facilities on project sites with the } \\
\text { COVID-19 protocol issued by the government } \\
\text { Follow up on the execution of construction services }\end{array}$ \\
\hline 3 & $\begin{array}{l}\text { Provision of health } \\
\text { facilities on sites }\end{array}$ & Contractor & $\begin{array}{l}\text { Contractors have the obligations to: } \\
\text { Provide adequate health clinic on sites } \\
\text { Has operational cooperation with the nearest hospital and/or } \\
\text { community health center for emergency measures }\end{array}$ \\
\hline
\end{tabular}


Table 3. Mechanism of the COVID-19 outbreak prevention in construction services sector (cont)

\begin{tabular}{|c|c|c|c|}
\hline No & Stage & Responsibility & Key Points \\
\hline & & & $\begin{array}{l}\text { Provide additional facilities such as hand washing, wipes, and } \\
\text { masks } \\
\text { Provide vaccines, vitamins and additional nutrients to increase } \\
\text { workers' immunity }\end{array}$ \\
\hline 4 & $\begin{array}{l}\text { Prevention of COVID- } \\
19 \text { on sites }\end{array}$ & $\begin{array}{l}\text { Employer and } \\
\text { contractor }\end{array}$ & $\begin{array}{l}\text { The task force provides flyers on COVID-19 prevention } \\
\text { The task force together with medical staff convey explanations, } \\
\text { suggestions, and the promotion of COVID-19 prevention in } \\
\text { every safety morning talk } \\
\text { Medical staff along with security staff carry out measurements } \\
\text { of the body temperature of the workers } \\
\text { The task force forbids people who are indicated to have a body } \\
\text { temperature of more than } 38 \text { degrees Celsius } \\
\text { If workers are found as patients under surveillance, work must } \\
\text { be stopped temporarily for at least } 14 \text { working days } \\
\text { Medical staff assisted by security staff carry out evacuation and } \\
\text { spraying of disinfectants on all work sites, facilities and } \\
\text { equipment } \\
\text { Work suspension is carried out until the process of evacuation } \\
\text { and spraying disinfectants as well as the implementation of } \\
\text { health checks and isolation of workers who have made physical } \\
\text { contact with infected workers have finished }\end{array}$ \\
\hline
\end{tabular}

According to this instruction, a construction project can be temporarily suspended due to force majeure if the following are identified:

(1) has a high risk due to the project location is at the center distribution of the COVID-19 outbreak;

(2) a positive and/or a patient under surveillance status has been found; or

(3) the Heads of Ministries/ Institutions/ Agencies/ Regional Governments have issued regulations to temporarily stop activities due to force majeure event.

However, in the case that the project must be continued due to its nature and urgency as part of handling the social and economic impacts of COVID-19 outbreak, the project may proceed with the following provisions:

(1) get approval from the Minister of Public Works and Housing;

(2) implement the COVID-19 prevention protocol with high discipline and regularly reported by the task force;

(3) conduct a temporary suspension when a positive worker and/or patient under surveillance is found.

\subsection{Finding 3: COVID-19 Outbreak as a Force Majeure Event}

The cost of COVID-19 outbreak has been widely reported and continues today. It can be considered as a 'special' force majeure event. Although the experience of epidemic outbreaks has been repeated, this study shows that many regulations and standard forms have not yet included an epidemic outbreak as a force majeure event in the related provision. In this section, a case study was conducted to analyze whether the COVID-19 outbreak constitute a force majeure event based on the above characteristics.

Unforeseeable. In general, unforeseeable means not reasonably foreseeable by parties when they are entering into the contract. This can also imply an event that has very little chance of happening that it would have been unreasonable to have allowed for it. This is observed in the COVID-19 outbreak that occurred suddenly in December 2019. Neither party thought that an epidemic outbreak would occur, which later became a pandemic. Some might argue whether the COVID-19 outbreak is a foreseeable event given other previous epidemic outbreaks such as SARS 
and MERS. However, the similar arguments can be given against other events such as earthquakes and tornadoes which are considered as force majeure events. It is also undeniable that the scale of this outbreak is unprecedented (Duggan, 2020). The Indonesian government has recognized it as an unforeseeable event (LKPP, 2020).

Unavoidable. It means that neither party could prevent the occurrence of the event or circumstance. This can be observed in the COVID-19 outbreak where since its appearance in December 2019, the spread has been very fast and alarming. On 11 March 2020, WHO declared it as a pandemic. All sectors, including construction industry has been affected by the outbreak. Its spread through human-to-human transmission makes labor-intensive industries such as construction at a greater risk of contracting this virus. Related to the contractual relations of the parties, neither party could prevent the occurrence of this crisis.

Uncontrollable. It refers to the incapability of contracting parties to control the event and its impact. As the status and level of distribution continues to increase, many governments have taken steps to limit human activities and interactions such as physical distancing and lockdowns. For instance, in Indonesia as of 12 April 2020, the Ministry of Health has established a large-scale social restriction in Jakarta, Bogor Regency, Bogor City, Depok City, Bekasi Regency, and Bekasi City through the Minister of Health Decree No. HK.01.07/MENKES/239/2020 and HK.01.07/MENKES/248/2020. This shows the development of the COVID-19 outbreak has become beyond the control of the contracting parties.

Impracticable. This refers to the condition where the event and its impact have adversely affected the fulfillment of contractual obligations. The handling of COVID-19 outbreak has direct and indirect impacts on the construction industry including disruption to supply chain logistics, delays, suspensions, terminations, and insolvencies (Bleby, 2020; Johnson, Moore \& Mitha, 2020; LKPP, 2020).

Beyond a party's responsibility. It means that the event is not substantially attributable to a party. In the case of the COVID-19 outbreak, both contracting parties do not have control or responsibility in accordance with the terms of the contract (unless previously stated in the contract). It is a global health issue that causes many governments in the world to declare a national disaster (Kabiling, 2020; Purnamasari, 2020; Xinhua, 2020). Some countries have declared it as a force majeure event as observed in French (Thomas \& Kar-Gupta, 2020), India (Gupta, 2020), China (Baker McKenzie, 2020), and Indonesia (LKPP, 2020).

Table 4 summarizes a comparative analysis of the COVID-19 outbreaks in terms of force majeure fundamental aspects. Apart from the discussion above, determination whether an event can be considered as a force majeure event or not is a decision determined by the governing law (Jaegar \& Hök, 2010). Therefore, decisions related to force majeure events may vary under different jurisdictions.

Table 4. Comparative analysis of force majeure and COVID-19 outbreak

\begin{tabular}{lll}
\hline Characteristics & Description & As observed in COVID-19 outbreak \\
\hline Unforeseeable & $\begin{array}{l}\text { not reasonably foreseeable by } \\
\text { parties when they are } \\
\text { entering into the contract }\end{array}$ & $\begin{array}{l}\text { This sudden outbreak appeared in Wuhan, China, which later } \\
\text { spread throughout the world on an unprecedented scale }\end{array}$ \\
\hline Unavoidable & $\begin{array}{l}\text { neither party could prevent } \\
\text { the occurrence of the event or } \\
\text { circumstance }\end{array}$ & $\begin{array}{l}\text { All sectors including construction were affected by this } \\
\text { incapability of contracting } \\
\text { parties to control the event } \\
\text { and its impact }\end{array}$ \\
&
\end{tabular}


Table 4. Comparative analysis of force majeure and COVID-19 outbreak (Cont.)

\begin{tabular}{lll}
\hline Characteristics & Description & As observed in COVID-19 outbreak \\
\hline Impracticable & $\begin{array}{l}\text { the event and its impact have } \\
\text { adversely affected the } \\
\text { fulfillment of contractual } \\
\text { obligations }\end{array}$ & $\begin{array}{l}\text { This outbreak has direct and indirect impacts on the } \\
\text { construction industry including disruption to supply chain }\end{array}$ \\
& $\begin{array}{l}\text { the event is not substantially, delays, suspensions, terminations, and insolvencies } \\
\text { Beyond } \\
\text { responsibility }\end{array}$ & $\begin{array}{l}\text { It is a global health disease which many countries declared as } \\
\text { attributable to a party }\end{array}$ \\
\hline
\end{tabular}

\section{DISCUSSION}

Based on the above findings, force majeure events can be generally divided into two types in terms of its duration and severity:

a) Permanent force majeure. A force majeure is said to be permanent if the carrying out of the whole or substantially the whole of the uncompleted works is suspended for the relevant continuous period of the length stated in the contract particulars, and the performance of the contract is no longer possible. The result of this permanent force majeure is contract termination as mentioned in Subclause 18.5 of FIDIC Red Book, Subclause 91.7 of NEC4, and Subclause 8.11 of JCT SBC/Q.

b) Temporary force majeure. Conversely, a force majeure is said to be temporary if the fulfillment of the performance of the contract is not possible only temporarily, where after the event stops, the performance can be fulfilled again. Therefore, the consequence of temporary force majeure is suspension and extension of time.

Meanwhile, the force majeure events generally can be divided into three groups based on its origins:

a) Natural events. These are force majeure events caused by natural disasters or Acts of God, without human intervention. These are usually origins from atmospheric, geologic, and hydrologic causes and may include earthquakes, floods, forest fires, volcanic eruptions, tornadoes, tsunamis, landslides, etc.

b) Political events. These are force majeure events caused by political situations and policies such as acts of terrorism, riots, wars, strikes, changes of law, or government interventions.

c) Special events. These refer to force majeure events other than those that fall into the two categories above. For instance, epidemic outbreaks that can be related to natural disasters (the risk for outbreak follows natural disasters) or suddenly appear and not related to natural disasters such as COVID-19 outbreak that is classified as a non-natural disaster under Article 1(3) of the Indonesian Law No. 24 of 2007 concerning Disaster Management.

In addition, several force majeure characteristics can also be identified from the above findings: (a) the event must have been unforeseeable at the time of contracting, (b) the occurrence must be unavoidable, (c) the event must be beyond the reasonable control of the affected party /impossible to overcome, $(\mathrm{d})$ the event adversely and materially affects the ability to perform, and (e) the event and its impact are not substantially attributable to a party.

On the other hand, this study also found that the terms epidemic, pandemic or disease are rarely listed as one of the force majeure events. According to Ezeldin and Helw (2018), courts usually tend to interpret force majeure clauses narrowly so that force majeure covers only the listed events and similar ones. For instance, if an force majeure clause mentions an act of a labor strike is an force majeure event, this does not mean that the courts will assume the threat of a labor strike as a force majeure event. Thus, Ryan (2011) suggested that it is crucial to list explicitly the circumstances in the force majeure clause. 
The success of reliance on a force majeure clause is very dependent on how it is drafted. Therefore, this study develops a decision model to assist the contracting parties in determining whether an event constitutes a force majeure event in their construction contract. This model, as illustrated in Figure 1, explains the process flow of determining an event from occurring to possible actions that can be carried out. Although being simple, this model is easy to understand and universally applicable.

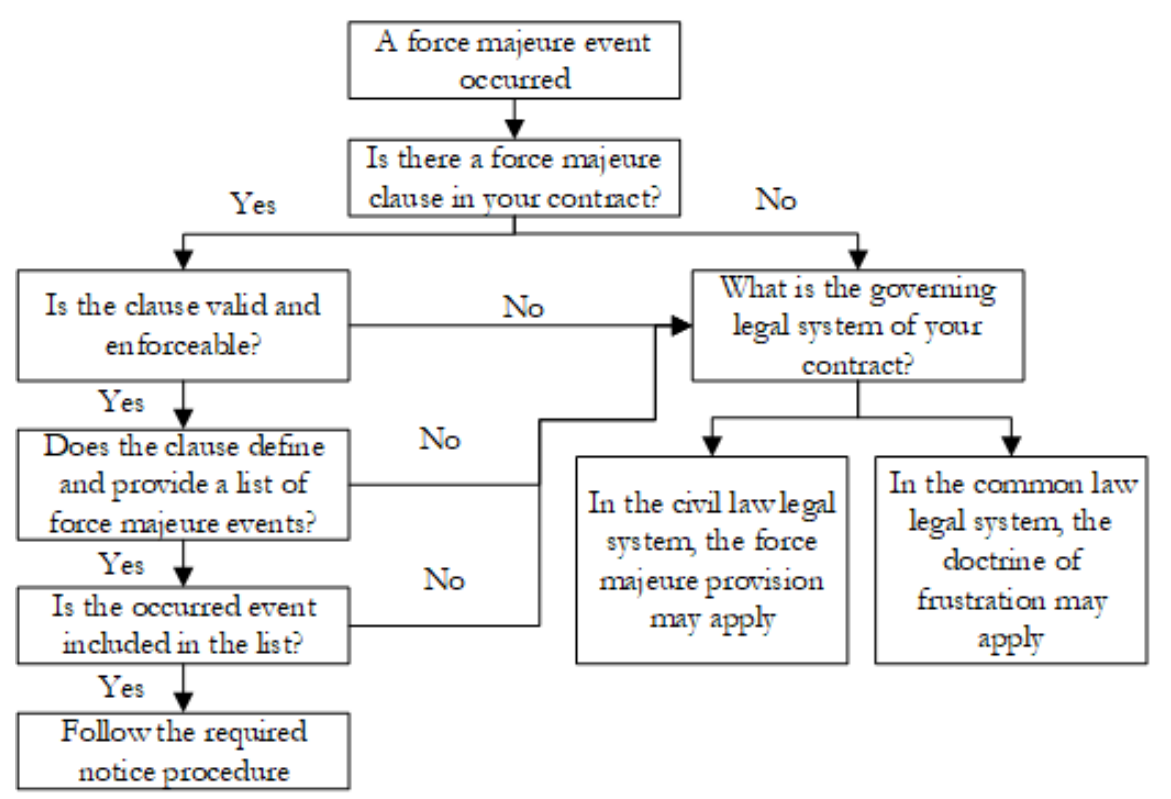

Figure 1. Force majeure decision model

To complete the above model, the following should be considered:

a) Other than force majeure clause, it is essential to understand other related provisions which may apply such as suspension, termination, and notification procedures in the contract.

b) It is vital to prepare a well-drafted force majeure clause, for example by including an epidemic outbreak as a force majeure event.

c) In addition to provide notice, the affected party must act with due diligence. Therefore, ensure that reasonable steps to avoid or mitigate the consequences of force majeure events have been taken.

d) Consider whether the event has significantly affected the performance of a party and become the main cause of the party's nonperformance. For this reason, it is important for the affected party to record and maintain the evidence of disruption caused by the event.

e) Consider the various outcomes that might follow force majeure events such as renegotiation, suspension, or termination. Parties may seek professional legal advice to ascertain their contractual rights when necessary.

\section{CONCLUSION}

The effects of the COVID-19 outbreak have highlighted the importance of a comprehensive and well drafted force majeure clause. The presence of force majeure clauses is imperative to avoid conflicts and disputes that arise from nonperformance due to force majeure events. Force majeure clause is an effort to reduce further losses due to exceptional circumstances even though the party has taken all reasonable precautions and due care to avoid or reduce the impacts. This research has investigated the potential of COVID19 outbreak as a force majeure event. In addition, it also proposes a force majeure decision model to assist parties in exercising their force majeure provision. This paper contributes since research related to the impacts of epidemic or pandemic 
outbreaks (such as SARS, MERS, and COVID-19) on the construction industry has not been done extensively. Future research recommendations may include investigation related to the impact of an epidemic outbreak on the growth of construction industry, the consequences of an epidemic outbreak on the implementation of work on project sites, and quantitative research related to the impact of an epidemic outbreak on project overhead costs and cashflow. While this research has discussed the potential of COVID-19 outbreak as a force majeure event, it should be noted that none of the findings and statements contained in this paper are intended to serve as a legal advice.

\section{DISCLAIMER}

The author declares no conflict of interest.

\section{ACKNOWLEDGMENTS}

The author would like to express his gratitude to RMIT University, Universitas Agung Podomoro, and Lembaga Pengelola Dana Pendidikan (LPDP) Republik Indonesia for supporting this research.

\section{REFERENCES}

Akbiyikli, R., Dikmen, S. U., and Eaton, D., 2011. Insurance Issues and Design and Build Construction Contracts. Proceeding of 6. İnşaat Yönetimi Kongresi, 25-26-27 Kasım 2011, Bursa (6. Construction Management Congress, 25-27 November 2011, Bursa, Turkey), 96-113.

Amkhan, A., 1991. Force majeure and impossibility of performance in Arab contract law. Arab Law Quarterly, 6(3), 297-308.

Augenblick, M., and Rousseau, A. B., 2012. Force majeure in tumultuous times: Impracticability as the new impossibility. The Journal of World Investment \& Trade, 13(1), 59-75.

Azfar, F., 2012. The Force Majeure "Excuse”. Arab Law Quarterly, 26(2), 249-253.

Baker McKenzie., 2020. Coronavirus Outbreak: Global Guide to Force Majeure and International
Commercial Contracts. [Online] Available at: https://www.bakermckenzie.com/en/insight/publ ications/2020/03/ coronavirus-outbreak-globalguide [Accessed on 4 March 2020].

Bleby, M., 2020. Construction feels COVID-19 delays in supply chain. [Online] Available at: https://www.afr.com/

property/commercial/construction-feels-covid19-delays-in-supply-chain-20200304-p546pv [Accessed on 4 March 2020].

Chang, L., Yan, Y., and Wang, L., 2020. Coronavirus Disease 2019: Coronaviruses and Blood Safety. Transfusion Medicine Reviews (preproof).

Contract Law of the People's Republic of China 1999.

Corrada, S. M. G., 2007. The best laid plans: Force majeure clauses in travel and event contracts. Nova Law Review, 31(3), pp. 409-421.

Duggan, J., 2020. Coronavirus outbreak declared a global public health emergency 'on an unprecedented scale' by World Health Organisation. [Online] Available at: https://www.thesun.co.uk/news/10858409/coron avirus-outbreak-world-health-organisation/ [Accessed on 20 March 2020].

El Zowalaty, M. E., and Järhult, J. D., 2020. From SARS to COVID-19: A previously unknown SARSCoV-2 virus of pandemic potential infecting humans - Call for a One Health approach. One Health (pre-proof). https://doi.org/10.1016/j.onehlt.2020.100124

Ezeldin, A. S., and Helw, A. A., 2018. Proposed Force Majeure Clause for Construction Contracts under Civil and Common Laws. Journal of Legal Affairs and Dispute Resolution in Engineering and Construction, 10(3), 04518005.

Fawzy, S. A., and El-Adaway, I. H., 2012. Contract Administration Guidelines for Managing Conflicts, Claims, and Disputes under World Bank-Funded Projects. Journal of Legal Affairs and Dispute Resolution in Engineering and Construction, 4(4), pp. 101-110. 
Fenwick Elliot LLP., 2014. Ebola \& Isis: force majeure under the standard forms. Insight Issue 41, November 2014.

FIDIC, 1999. Conditions of Contract for Construction. Geneva: FIDIC.

FIDIC, 2017. Conditions of Contract for Construction $2^{\text {nd }}$ edition. Geneva: FIDIC.

French Civil Code 2016. The Law of Contract, the General Regime of Obligations, and Proof of Obligations. The new provisions of the Code Civil created by Ordonnance no. 2016-131 of 10 February 2016.

General Rules of the Civil Law of the People's Republic of China 2017.

Gupta, U., 2020. Solar projects reprieved as Indian government declares coronavirus a force majeure. PV Magazine. [Online] Available at: https://www.pv-

magazine.com/2020/02/24/solar-projectsreprieved-as-indian-government-declarescoronavirus-a-force-majeure/ [Accessed on 14 March 2020].

Hagedoorn, J., and Hesen, G., 2007. Contract law and the governance of inter-firm technology partnerships: An analysis of different modes of partnering and their contractual implications. Journal of Management Studies, 44(3), 342-366.

Hansen, S., Too, E., and Le, T., 2018. Retrospective look on front-end planning in the construction industry: A literature review of 30 years of research. International Journal of Construction Supply Chain Management, 8(1), 1942.

Holcim Singapore Pte. Ltd v Precise Development Pte Ltd [2011] SGCA 1.

Indonesian Civil Code (KUHPer).

Indonesian Law No. 24 of 2007 concerning Disaster Management.

Instruction of Ministry of Public Works and Housing No. 02/IN/M/2020 concerning Protocol for Preventing the Spread of Corona Virus Disease 2019 (COVID-19) in the Construction Services.

Jaegar, A., and Hök, G., 2010. FIDIC - A guide for practitioners. Discharge, frustration and force majeure. Berlin: Springer.

JCT, 2016. Standard Building Contract with Quantities 2016 (SBC/Q 2016). London: Thomson Reuters, Sweet \& Maxwell.

Johnson, N., Moore, R., and Mitha, Y., 2020. Is COVID-19 likely to be a valid basis for avoiding contractual obligations? [Online] Available at: https://www.herbertsmithfreehills.com/latestthinking/is-covid-19-likely-to-be-a-valid-basisfor-avoiding-contractual-obligations [Accessed on 14 March 2020].

Kabiling, G., 2020. Duterte declares state of calamity over $\mathrm{PH}$ for next 6 months amid rise in COVID-19 cases. [Online] Available at: https://news.mb.com.ph/2020/03/17/dutertedeclares-state-of-calamity-over-ph-for-next-6months-amid-rise-in-covid-19-cases/ [Accessed on 20 March 2020].

Lai, C. C., Shih, T. P., Ko, W. C., Tang, H. J., and Hsueh, P. R., 2020. Severe acute respiratory syndrome coronavirus 2 (SARS-CoV-2) and corona virus disease-2019 (COVID-19): the epidemic and the challenges. International Journal of Antimicrobial Agents. doi: https://doi.org/10.1016/j.ijantimicag.2020.10592 4

\section{Li Ching Wing v Xuan Yu Xiong [2004] 1 HKLRD} 754.

Li, J., and Zou, P., 2012. Risk identification and assessment in PPP infrastructure projects using fuzzy analytical hierarchy process and life-cycle methodology. Australasian Journal of Construction Economics and Building, 8(1), pp. 34-48.

LKPP (Lembaga Kebijakan Pengadaan Barang/Jasa Pemerintah), 2020. Pelaksanaan Kontrak Pengadaan Barang/Jasa Pemerintah Terkait COVID-19. [Online pdf] Available at: https://www.covid19.go.id/download/pelaksanaa 
n-kontrak-pengadaan-barang-jasa-pemerintahterkait-covid-19/ [Accessed on 12 April 2020].

Ministry of Health Decree No. HK.01.07/MENKES/239/2020 concerning

Determination of Large-Scale Social Restrictions in Jakarta Province in Acceleration Handling of Corona Virus Disease 2019 (COVID-19).

Ministry of Health Decree No. HK.01.07/MENKES/248/2020 concerning Determination of Large-Scale Social Restrictions in the Bogor Regency, Bogor City, Depok City, Bekasi Regency, and Bekasi City, West Java Province in Acceleration Handling of Corona Virus Disease 2019 (COVID-19).

NEC, 2017. NEC4 Engineering and Construction Contract $4^{\text {th }}$ edition. London: Thomas Telford Ltd.

Purnamasari, D. M., 2020. BNPB: Wabah COVID19 di Indonesia Bencana Skala Nasional. [Online] Available at: https://nasional.kompas.com/read/2020/03/17/1 7455041/bnpb-wabah-covid-19-di-indonesiabencana-skala-nasional [Accessed on 20 March 2020].

Rothan, H. A., and Byrareddy, S. N., 2020. The epidemiology and pathogenesis of coronavirus disease (COVID-19) outbreak. Journal of Autoimmunity (in press). https://doi.org/10.1016/j.jaut.2020.102433

Ryan, J. M., 2011. Understanding force majeure clauses. [Online] Available at: https://www.venable.com/understanding-forcemajeure-clauses-2-25-2011/ [Accessed 5 March 2020].
Seadrill Ghana Operations Ltd v Tullow Ghana Ltd [2018] EWHC 1640.

Thames Valley Power Ltd $v$ Total Gas \& Power Ltd [2006] 1 Lloyd's Rep. 441.

Thomas, L., and Kar-Gupta, S., 2020. France: "force majeure" can be declared over coronavirus in contracts with smaller firms. [Online] Available at: https://www.reuters.com/article/us-chinahealth-france-economy/france-force-majeurecan-be-declared-over-coronavirus-in-contractswith-smaller-firms-idUSKCN20M1R8 [Accessed on 4 March 2020].

Torraco, R. J., 2005. Writing integrative literature reviews: Guidelines and examples. Human Resource Development Review, 4(3), 356-367.

World Health Organization (WHO), 2020. WHO Director-General's opening remarks at the media briefing on COVID-19 - 11 March 2020. [Online] Available at:

https://www.who.int/dg/speeches/detail/whodirector-general-s-opening-remarks-at-themedia-briefing-on-covid-19---11-march-2020 [Accessed on 17 March 2020].

Worldometer, 2020. COVID-19 Coronavirus Outbreak Update. [Online] Available at: https://www.worldometers.info/coronavirus/ [Accessed on 12 April 2020].

Xinhua, 2020. Zimbabwe's President declares COVID-19 a national disaster. [Online] Available at:

https://www.iol.co.za/news/world/zimbabwespresident-declares-covid-19-a-nationaldisaster-45134184 [Accessed on 20 March 2020]. 